\title{
STRES PADA REMAJA PUTERI YANG MENGALAMI DYSMENORRHEA DI KOTA BANDAR LAMPUNG
}

\author{
Ayudiah Pangesti*, R. Pranajaya*, Nurchairina* \\ *Jurusan Kebidanan Poltekkes Tanjungkarang \\ E-mail: ina.wirman@yahoo.com
}

\begin{abstract}
Dysmenorrhea merupakan kejadian yang sering dialami para wanita khususnya remaja yang berusia 1020 tahun. Angka kejadian di Bandar Lampung masih tinggi, yaitu 71,4\%. Kejadian dysmenorrhea menyebabkan sebagian besar remaja mengalami stres. Penelitian ini merupakan penelitian analitik korelasional dengan pendekatan cross sectional. Populasi adalah seluruh siswi sebuah sekolah di Bandar Lampung, dengan jumlah sampel sebanyak 80 sampel yang ditetapkan dengan teknik random sampling. Data yang diambil adalah data primer, alat yang digunakan berupa kuesioner. Analisis data yang digunakan adalah analisis univariat dengan persentase dan bivariat dengan Chi Square. Hasil penelitian responden yang mengalami stress $76 \%$, kemudian yang mengalami dysmenorrhea primer $81 \%$. Hasil uji statistik dapat disimpulkan ada hubungan yang signifikan antara stress dengan kejadian dysmenorrhea primer dengan $p$-value 0,003dan $\mathrm{OR}=5,610$. Saran bagi petugas kesehatan di sekolah-sekolah agar dapat melakukan kegiatan non akademik di sekolah seperti senam setiap seminggu sekali untuk merelaksasikan diri serta memberikan pendidikan kesehatan tentang stress dan dysmenorrhea primer pada siswi setiap sebulan sekali untuk meningkatkan pengetahuan dan mengetahui cara pencegahan penanganan ketika mengalami stress dan dysmenorrhea primer.
\end{abstract}

Kata kunci: Dysmenorrhea, stress

\section{LATAR BELAKANG}

Dismenore merupakan nyeri yang terjadi saat haid, biasanya dengan rasa kram dan terpusat pada abdomen bagian bawah yang menjalar kepunggung bawah sampai kepaha.Biasanya dismenore ini juga disertai dengan mual, muntah, pusing, hingga diare. Keluhan ini dapat terjadi bervariasi mulai dari yang ringan sampai berat. Nyeri yang dimaksud yaitu nyeri yang menyebabkan aktifitas sehari-hari terganggu serta menyebabkan perempuan tidak bisa melanjutkan pekerjaannya bahkan sampai harus datang berobat kedokter atau mengobati dirinya sendiri dengan obat anti nyeri (Sarwono, 2013).

Oleh karena itu, setiap perempuan mengharapkan ketika sedang berlangsung nya haid para perempuan tidak merasakan atau mengalami dismenore/ nyeri haid yang berlebihan agar bisa tetap merasa nyaman selama haid dan tidak mengganggu aktifitas sehari-hari, serta tidak mempengaruhi fisik, emosional, social seorang perempuan. Normalnya perempuan tidak merasakan dismenore secara berlebihan serta menstruasi berlangsung selama 7-8 hari Dismenore memiliki dampak negative bagi keseharian para remaja.Dampak tersebut antara lain berkurangnya konsentrasi, ketidak nyamanan saat menstruasi serta mengganggu aktivitas dan pekerjaanwanita

Desminore menimbulkan perasaan yang tidak nyaman dan asing.Sedikit tidak merasa nyaman dan dapat dengan cepat berkembang menjadi suatu masalah besar dengan segala kekesalan yang menyertainya.Dismenore tidak hanya menyebabkan gangguan aktivitas tetapi juga memberi dampak baik dari segi fisik, psikologis, social, dan ekonomi terhadap perempuan misalnya, cepat letih, dan lebih sering marah. Dampak psikologinya dapat berupa konflik emosional, ketegangan, dan kegelisahan, hal tersebut dapat menimbulkan perasaan yang tidak nyaman dan asing, yang nantinya akan mem pengaruhi kecakapan dan keterampilannya.

Nyeri haid merupakan karakteristik kram yang terjadi pada abdomen bagian bawah yang menjalar kepunggung bawah hingga kepaha,biasanya kram ini terjadi 
selama atau sebelum menstruasi, serta mencapai puncaknya dalam waktu 24 jam, namun setelah 2 hari akan menghilang. Nyeri ini terjadiselama.1-2 hari saat menstruasi (A. Qadir, 2017). Karena gangguan ini bersifat subyektif, berat atau intensitasnya sukar dinilai walaupun frekuensi dismenore cukup tinggi dan penyakit ini sudah lama dikenal,namun sampai sekarang potogenesisnya belum dapat dipecahkan dengan memuaskan (Prawirohardjo, 2008).

Angka kejadian dismenore berdasarkan data dari Dinas Kesehatan Provinsi Lampung tahun 2007, data dismenore belum bisa diklasifikasikan. Angka kejadian dismenore primer pada remaja diperkirakan 1,2\% sampai 1,35\% dari jumlah penderita yang memeriksakan dirinya kepetugas kesehatan (Profil Kesehatan Lampung, 2007). Berdasarkan informasi yang didapat sumber informasi dari Dinas Kesehatan Lampung, data dismenore terakhir hanya ditemui sampai tahun 2007.Karena kondisi di Indonesia banyak perempuan yang mengalami dismenore tidak melaporkan dirinya kedokter atau tenaga kesehatan sehingga pendataan tentang dismenore tidak bisa diklasifikasikan.Rasa meremehkan inilah yang menyebabkan penderita penyakit tertentu sampai saat ini belum bisa dipastikan secaramutlak (Dito Anurogo, 2011).

Hasil survei dari Perkumpulan Keluarga Berencana Indonesia (PKBI) cabang Bandar Lampung tahun 2014, dismenore menempati urutan pertama keluhan yang sering dialami wanita, yaitu sebesar $65,3 \%$. Selain siklus menstruasi yang tidak teratur.Prevalensi dismenore, lebih tinggi pada kelompok usia remaja 1020 tahun sebesar 71,4\% (PKBI Bandar Lampung, 2014). Penyebab terjadinya nyerihaid/ dismenore ini belum diketahui pasti, tetapi etiologi dari dismenore primer salah satunya yaitu factor psikis kejiwaan (stress).Sedangkan dari beberapa teori penyebab dismenore primer disebutkan bahwa kontraksi myometrium akan menyebabkan iskemia pada uterus sehingga menyebabkan rasa nyeri.
Kontraksi myometrium tersebut disebabkan oleh sintesis prostaglandin. Prostaglandin disebut dapat mengurangi atau menghambat sementara suplai darah ke uterus, yang menyebabkan uterus mengalami kekurangan oksigen sehingga menyebabkan kontraksi myometrium dan terasa nyeri .Penyebab dismenore lainnya yaitu factor endokrin, kelainan organic, factor kejiwaan atau gangguan psikis, factor konstitusi, dan factor alergi. Sedangkan factor risiko terjadinya dismenore primer ialah menarche pada usia lebih awal, belum pernah hamil dan melahirkan, lama menstruasi lebih dari normal 7 hari, dan umur.Wanita yang menderita dismenore primer biasanya wanita yang mengkonsumsi alcohol, perokok, tidak pernah berolahraga, dan stress (Dito A, 2011).

Berdasarkan pra survei yang dilakukan dilakukan di beberapa SMA di Bandar Lampung yaitu, SMAN 5 Bandar Lampung, SMAN 12 Bandar Lampung SMKN 8 Bandar Lampung, data yang dismenore tertinggi berada pada SMKN 8 Kemiling Bandar Lampung. Hasil data SMKN 8 Kemiling didapat dari hasil data UKS yaitu pada tahun 2015, terdata dengan persentase $(7,4 \%)$ sebanyak 36 orang dari 483 siswi di SMK 8 Kemiling yang terdata berobat ke UKS. Sedangkan pada tahun 2016 terdata $(8,7 \%)$ sebanyak 42 orang dari 483 siswi yang berobat ke UKS SMK 8 Kemiling. Dari data diatas terlihata danya peningkatan kejadian dismenore dari tahun 2015 ketahun 2016.Sedangkan tahun 2017 sebanyak $(10,1 \%) 49$ siswi dari 483 siswi di SMKN 8 Kemiling Bandar Lampung. Sedangkan data khusus siswi yang memilih beristirahat dirumah dari 49 siswi tercatat sebanyak $22(4,5 \%)$ siswi memilih untuk beristirahat dirumah.

Data khusus siswi kelas XII yang mengalami dismenore/nyeri haid sebesar (11\%) yaitu19 orang dari 168 siswi kelas XII di SMKN 8 Kemiling Bandar Lampung. Dari hasil wawancara yang dilakukan pada tanggal 27 November 2017 di SMKN 8 Kemiling, sebesar (40\%) dari 15 orang sebanyak 6 siswi mengatakan 
mengalami dismenore ketika sedang menstruasi. Kebanyakan dari siswi yang mengalami dismenore mengaku pernah tidak hadir beristirahat dirumah atau memilih untuk beristirahat di UKS ketika mengalami dismenore. Dari prasurvey diatas juga didapatkan hasil bahwa sebagian besar siswi yang mengalami dismenorrhea juga mengalami stress. Sebagian besar siswi yang mengalami stress akibat ujian yang sudah semakin dekat, kurangnya waktu istirahat, padatnya jam pelajaran di sekolah serta faktor lain yang dapat menimbulkan stress.

\section{METODE}

Rancangan penelitian yang digunakan adalah penelitian analitik dengan pendekatan crossectional. Populasi dalam penelitian adalah sremaja puteri di Kota Bandar Lampung dengan jumlah sampel sebanyak 80 responden. Teknik sampel penelitian menggunakan probability dengan random sampling. Data penelitian berupa data primer yang dikumpulkan dengan menggunakan kuesioner. Data selanjutnya diolah dan dilakukan analisis. Data dianalisis menggunakan analisis univariat berupa persentase dan analisis bivariat dengan uji Chi Square dengan bantuan perangkat lunak komputer.

\section{HASIL}

\section{Analisis Univariat}

Tabel 1: Distribusi frekwensi kejadian dysmenorhea

\begin{tabular}{lcc}
\hline \multicolumn{1}{r}{ Dysmenorhea } & f & $\%$ \\
\hline Ya & 65 & 81 \\
\hline Tidak & 15 & 19 \\
\hline Jumlah & 80 & 100 \\
\hline
\end{tabular}

Pada penelitian ini kejadian dysmenorhea sebesar $81 \%$, sedang yang tidak mengalami dysmenorhea $19 \%$.
Tabel 2: Distribusi Frekuensi Kejadian Stres

\begin{tabular}{lccc}
\hline & Stres & f & $\%$ \\
\hline Ya & 61 & 76 \\
\hline Tidak & 19 & 24 \\
\hline Jumlah & 80 & 100 \\
\hline
\end{tabular}

Pada penelitian ini rmaja puteri yang mangalami stres sebanyak $76 \%$, sedang yang tidak mengalami stres $24 \%$.

Tabel 3: Analisis hubungan antara stres dan kejadian dysmenorrhea

\begin{tabular}{lcccccc}
\hline \multirow{2}{*}{ Stres } & \multicolumn{4}{c}{ Dismenorhea } & \multirow{2}{*}{ Total } \\
\cline { 2 - 6 } & \multicolumn{2}{c}{ Ya } & \multicolumn{2}{c}{ Tidak } & \multicolumn{2}{c}{} \\
\cline { 2 - 6 } & $\mathrm{f}$ & $\%$ & $\mathrm{f}$ & $\%$ & $\mathrm{f}$ & $\%$ \\
\hline Ya & 54 & 88,5 & 7 & 11,5 & 61 & 100 \\
\hline Tidak & 11 & 57,9 & 8 & 42,1 & 19 & 100 \\
\hline Jumlah & 65 & 81,25 & 15 & 18,75 & 80 & 100 \\
\hline p value & 0,003 & & & & \\
\hline OR CI 95\% & 5,61 & $(1,6-18,3)$ \\
\hline
\end{tabular}

Hasil analisis hubungan stress dengan kejadian dysmenorhea diperoleh bahwa ada sebanyak $54(88,5 \%)$ siswi yang stres mengalami dysmenorhea, sedangkan diantara siswi yang tidak stres ada $11(57,9 \%)$ mengalami dysmenorhea. Hasil uji statistik diperoleh nilai $p=0,003$ maka dapat disimpulkan ada hubungan yang signifikan antara stres dengan kejadian dismenorhea. Dari hasil analisis diperoleh pula nilai $\mathrm{OR}=5,610$, artinya siswi yang stres mempunyai peluang 5,610 kali untuk mengalami kejadian dismenorhea dibanding siswi yang tidak stres.

\section{PEMBAHASAN}

Penelitian ini menemukan sebagaian besar remaja puteri di Kota Bandar Lampung mangalami dysmenorrhea saat menstruasi $(81 \%)$. Hasil penelitian ini lebih tinggi dibandingkan dengan hasil penelitian yang dilakukan oleh Febriana Marlindiastuti (2013) bahwa dari 108 responden yang mengalami dysmenorrhea sebesar 69,45\%. Penelitian ini sesuai dengan kerangka teori Dito Anurogo (2011) yang menyatakan kejadian 
dysmenorrhea muncul akibat kontraksi disritmik myometrium yang menampilkan satu gejala atau lebih, mulai dari nyeri yang ringan sampai berat di perut bagian bawah, bokong, dan yeri spasmodic di sisi medial paha. Penyebab stress yaitu suatu tekanan. Tekanan yang timbul sebagai akibat adanya tekanan hidup sehari-hari. Stresor tersebut dirasakan dan sipersepsikan oleh individu sebagai suatu ancaman sehingga menimbulkan kecemasan yang nantinya akan menyebabkan timbulnya dysmenorrhea .

Dysmenorrhea adalah nyeri yang terjadi saat haid, biasanya dengan rasa kram dan terpusat pada abdomen bagian bawah yang biasanya juga disertai dengan mual, muntah, pusing, hingga diare. Keluhan ini dapat terjadi bervariasi mulai dari yang ringan sampai berat. Nyeri yang dimaksud yaitu nyeri yang menyebabkan aktifitas sehari-hari terganggu serta menyebabkan perempuan tersebut sampai datang berobat ke dokter atau mengobati dirinya sendiri dengan obat anti nyeri (Sarwono, 2013). Selama menstruasi, selsel endometrium yang terkelupas melepaskan prostaglandin (kelompok prsenyawaan mirip hormone kuat yang terdiri dari asam lemak esensial. Prostaglandin menyebabkan kontraksi myometrium (otot dinding rahim) yang kuat dan mampu menyempitkan pembuluh darah, mengakibatkan iskemia (penurunan suplai darah ke rahim), perdarahan, dan nyeri (Geri M \& Carole H, 2009). Peningkatan kadar prostaglandin telah terbukti ditemukan pada cairan haid pada perempuan dengan dismenore berat. Kadar ini memang meningkat terutama selama dua hari pertama haid.(Dito Anurogo, 2011).

Peneliti menyarankan kepada sekolah untuk dilakukan suatu kegiatan setiap satu bulan sekali di sekolah yaitu kegiatan dalam memberikan pendidikan kesehatan atau penyuluhan tentang kesehatan reproduksi terhadap siswi di SMKN 8. Penyuluhan tersebuat dapat dilakukan oleh perawat UKS atau Puskesmas di wilayah tersebut. Penyuluhan tersebut dilakukan agar siswi mengetahui dan paham tentang kesehatan reproduksi serta agar dapat menambah pengetahuan para siswi dan dapat bermanfaat untuk pencegahannya.

Untuk itu dalam mengatasi masalah dysmenorrhea hendaklah dilakukan kegiatan penyuluhan yang dilakukan oleh puskesmas atau perawat UKS dan dapat dilakukan pencegahan seperti hindari stress sebisa mungkin dengan tenang. Beristirahat yang cukup, terapkan pola hidup sehat, hindari makanan pedas dan minuman yang dingin. Bisa juga dengan mengompress perut ketika sudah terjadi dysmenorrhea primer. Bisa juga diselingi dengan mendengarkan musik, membaca buku atau menonton film dalam upaya mengurangi rasa nyeri saat menstruasi.

\section{Stress}

Remaja puteri di Kota Bandar Lampung sebagian besar mengalami stres ketika menstruasi $(76 \%)$. Hasil penelitian ini lebih tinggi dibandingkan dengan penelitian yang dilakukan oleh Febriana Marlindiastuti (2013) yang menunjukkan bahwa persentase stress sedang $50,93 \%$ dan stress ringan dengan persentase 49,07\%. Penelitian ini sesuai dengan kerangka teori Dito Anurogo (2011) yang menyatakan bahwa faktor kejiwaan (stress) merupakan salah satu penyebab timbulnya nyeri saat menstruasi atau dysmenorrhea primer.

Stres adalah suatu kondisi atau keadaan tubuh yang terganggu karena tekanan psikologis. Biasanya stress dikaitkan bukan karena penyakit fisik, tetapi lebih karena masalah kejiwaan seseorang. Selanjutnya, stress beraibat pada penyakit fisik, yang bisa muncul akibat lemahnya dan rendahnya daya tahan tubuh seseorang pada saat stress menyerang (Yekti Mumpuni, 2010). Misalnya bagaimana respons tubuh seseorang yang bersangkutan mengalami beban pekerjaan yang berlebihan. Stress dapat menurunkan ketahanan terhadap rasa nyeri. Saat stress, tubuh akan memproduksi hormon adrenalin, estrogen, progesteron, dan prostaglandin yang 
berlebihan. Estrogen dapat meningkatkan kontraksi uterus secara berlebihan, sedangkan progesteron dapat menghambat kontraksi. Peningkatan kontraksi secara berlebihan ini menyebabkan rasa nyeri. Selain itu, hormon adrenalin juga meningkat sehingga menyebabkan otot tubuh menjadi tegang termasuk otot rahim dan dapat menyebabkan rasa nyeri ketika menstruasi (Isnaeni, 2010)

Peneliti menyarankan kepada sekolah untuk dilakukan suatu kegiatan setiap satu minggu sekali untuk membantu merelaksasikan siswi dengan membuat acara senam sehat atau pendidikan kesehatan yang berisi tentang cara penanganan terhadap stress yang dilakukan oleh perawat UKS atau Puskesmas di wilayah tersebut. Kegiatan tersebut dilakukan agar siswi dapat menambah pengetahuan dan paham tentang pencegahan atau penanganan yang dapat dilakukan ketika sedang stres.

Untuk itu dalam mengatasi masalah stress dapat dilakukan kegiatan yang merelaksasikan diri, dan menambah pengetahuan kesehatan. Agar para siswi bisa mencegah stress sebelum menimbulkan penyebab yang tidak diinginkan. Kegiatan yang dapat dilakukan seperti senam setiap seminggu sekali. Selain berfungsi untuk merileksasikan diri juga dapat menyehatkan tubuh.

\section{Stress pada Dymenorrhea Primer}

Hasil penelitian menyimpulkan bhwa ada hubungan antara stress dengan kejadian dysmenrrhea primer pada remaja putri. Penelitian ini sesuai dengan kerangka teori Dito Anurogo (2011) yang menyatakan kejadian dysmenorrhea dipengaruhi oleh beberapa faktor yang salah satunya yaitu kejiwaan atau stress. Penelitian ini mendukung penelitian sebelumnya yang dilakukan oleh Febriana Marlindiastuti (2013) bahwa adanya hubungan antara stress dengan kejadian dymenorrhea primer.

Stres dapat menurunkan ketahanan terhadap rasa nyeri. Saat stres, tubuh akan memproduksi hormon adrenalin, estrogen, progesteron, dan prostaglandin yang berlebihan. Estrogen dapat meningkatkan kontraksi uterus secara berlebihan, sedangkan progesteron dapat menghambat kontraksi. Peningkatan kontraksi secara berlebihan ini menyebabkan rasa nyeri. Selain itu, hormon adrenalin juga meningkat sehingga menyebabkan otot tubuh menjadi tegang termasuk otot rahim dan dapat menyebabkan rasa nyeri ketika menstruasi (Isnaeni, 2010). Stres yang berlarut-larut dan dalam intensitas yang tinggi dapat menyebabkan penyakit fisik dan mental seseorang yang akhirnya dapat menurunkan produktivitas kerja. Kondisi tubuh yang menurun, kurangnya olahraga atau pengaruh hormon ptostaglandin juga menjadi penyebab lainnya yang dapat memicu terjadinya dysmenorrhea.

Hasil penelitian ini menunjukkan seorang yang mengalami tingkat stress cenderung mengalami dysmenorrhea . peneliti berasumsi bahwa responden mengalami stress dikarenakan sudah mendekati Ujian Nasional. Adanya peningkatan aktivitas belajar di sekolah, adanya peambahan waktu pembelajaran di sekolah, adanya peningkatan kegiatan yang berhubungan dengan kurikulum sekolah serta adanya dilematika yang terdapat pada individu siswi itu sendiri untuk menentukan jenjang apa yang akan diambil setelah lulus SMA ini. Hal ini diduga menjadi penyebab timbulnya keluhan stress.

Untuk itu peneliti menyarankan kepada sekolah untuk dilakukan suatu kegiatan setiap satu bulan sekali yaitu kegiatan dalam memberikan pendidikan kesehatan atau penyuluhan tentang kesehatan reproduksi Penyuluhan tersebut dapat dilakukan oleh perawat UKS atau puskesmas di wilayah tersebut agar siswi mengetahui dan paham tentang kesehatan reproduksi dan agar siswi dapat mengetahui pencegahan yang dapat dilakukan sebelum menyebabkan masalah yang lebih lanjut. 


\section{KESIMPULAN}

Hasil penelitian menyimpulkan bahwa remaja puteri di Kota Bandar Lampung pada saat mengalami menstruasi sebagian besar mengalami dysmenorrhea dan sebagian besar juga mengalami stres. Hasil uji statistik menyimpulkan terdapat hubungan antara kejadian dismenorhea dengan stres $(p$ value $=0,003$ dan $\mathrm{OR}=$ 5,610 ).

Sleanjutnya penelitian ini menyarankan kepada sekolah-sekolah di Bandar Lampung agar melakukan kegiatan non akademik setiap seminggu sekali atau sebulan sekali. Kegiatan ini dapat dikordinir dan difasilitasi oleh perawat UKS atau perawat puskesmas. Kegiatan yang dapat dilakukan dapat berupa senam atau aktivitas fisik lainnya dan penyuluhan kesehatan tentang kesehatan tentang stress dan dysmenorrhea.

\section{DAFTAR PUSTAKA}

Anurogo, Dito. 2011. Cara Jitu Mengatasi Nyeri Haid. Yogyakarta: CV. Andi

Crawford, John \& Henry, Julie D, 2003.The Depession Anxiety Stress Sacle (DASS) : Normative Data and Latent Structure in a Large non-
Clinical Sampel . Department of Psychology, King'sCollege, University of Aberdeen, UK.

DepartemenKesehatan RI, 2007, Profil Kesehatan Lampung Tahun 2007.

Marlindi Astuti, Febriana. 2013. Hubungan Stress dan Anemia TerhadapKejadian Dysmenorrhea Primer padaMahasiswi Tingkat 1 DIII Kebidanan Poltekkes Tanjung Karang. Lampung, Skripsi Sarjana, Fakultas Kebidanan Politeknik Kesehatan, Bandar Lampung.

Mc Caffery, M \& Beebe, A, 1993.Pain Clinical Manual of Nursing Practice. Mosby, London.

Morgan, Geri dan Hamilton, Carole. 2009. Obstetri dan Ginekologi. Jakarta: EGC. Ed. 2.

Mumpuni, Yekti. 2010. Cara Jitu Mengatasi Stress. Yogyakarta: CV. Andi Offset.

PKBI (Perkumpulan Keluarga Berencana Indonesia) Bandar Lampung Tahun 2014, Lampung.

Prawirohardjo, Sarwono, 2013. Ilmu Kebidanan. Jakarta :Yayasan PT Bina PustakaSarwono.

Prawirohardjo, Sarwono, 2008. Ilmu Kebidanan. Jakarta :Yayasan PT Bina Pustaka Sarwono. 